\section{On Being Invisible in the Mental Health System}

\author{
Ann Jennings, Ph.D.
}

This chapter brings into question one of the basic assumptions operating in the public mental health field today: that mental illness is biological or genetic in origin and is therefore treatable primarily by symptom control or management. A case study of my daughter Anna, a victim of early childhood sexual trauma, is used to demonstrate the need for inclusion in the field of an additional view of the etiology of mental illness. Forces supporting the emergence of a new trauma paradigm are highlighted.

\section{ANNA'S STORY}

From the age of 13 to her recent death at the age of 32, Anna was viewed and treated by the mental health system as "severely and chronically mentally ill." Communication about who she was, how she was perceived and treated, and how she responded took place through

NOTE: The reader is forewarned that to provide a reallstic account of Anna's experience and her attempts to communicate it to others, explicit language and graphic descriptions of her behavior are included.

This chapter appeared as an article in the Journal of Mental Health Administration, 1994, Vol. 21, No. 4, pp. 374-387. her mental health records. A review of 17 years of these records reveals her described in terms of diagnoses, medications, "symptoms," behaviors, and treatment approaches. She was consistently termed "noncompliant" or "treatment-resistant." Initially recorded childhood history was dropped from her later records. Her own insights into her condition were not noted.

When she was 22, Anna was re-evaluated after a suicide attempt. For a brief period, she was rediagnosed as suffering from acute depression and a form of post-traumatic stress disorder. This was the only time in her mental health career that Anna agreed with her diagnosis. She understood herself-not as a person with a "brain disease," but as a person who was profoundly hurt and traumatized by the "awful things" that had happened to her.

\section{WHAT HAPPENED TO ANNA?}

Anna was bom in 1960, the third of five children, a beautiful, healthy baby with a wonderful disposition. At the age of about two and a half, she began to scream and cry inconsolably. At four, we took her to a child psychiatrist who found nothing wrong with her. When we placed her in nursery school, her problems seemed to lessen.

That Anna was being sexually abused and traumatized at the time is clear now, verified in later years by her own revelations and by the memories of others. Her memories of abuse by a male baby-sitter were vivid, detailed, and consistent in each telling over the years. They were further verified by persons close to the perpetrator and his family, one of whom witnessed the perpetrator years later in the act of abusing another child.

Anna described the experience of being forcibly restrained and sexually violated at the age of about three and a half: "He tied me up, put my hands over my head, blindfolded me with my little T-shirt, pulled my T-shirt over my head with nothing on below, opened my legs and was examining and putting things in me and all that ... ugh. It hurt me. I would cry and he wouldn't stop. To do that when I was a little kid was like... uh, I don't know ... it made me feel pretty bad. I remember after 
he did that I was walking toward the door out of the room and I was feeling like I was bad. And why not Sarah and Mary (her older and younger sisters) and why just me? And I had this feeling in me that I was bad, you know ... a bad seed ... and that I was the only one in the world."

Evidence that Anna was betrayed and sexually violated at an even earlier age by another perpetrator, a relative, came to light eventually through the revelations of a housekeeper whom Anna had confided in at the time. She had told this woman that a man "played with her where he wasn't supposed to" and that the man "hurted her." This abuse was kept secret for nearly 30 years.

Anna remembered trying to tell us, as a little child, what was happening, but there was no one to hear or respond. When she told me a man "fooled" with her, I assumed she meant a young neighborhood boy, and cautioned his parents. When we took her to a physician, she experienced the physical examination as yet another violation. "I remember the doctor you took me to when I told you. He did things to me that were disgusting (pointing to her genital area)."

The trauma Anna experienced was then compounded by the silence surrounding it. She tried to communicate with her rage, her screams, and her terror. She became the "difficult to handle" child. Her screaming and crying were frequently punished by spankings and confinement to her room. No one then could see or hear her truth; sexual abuse did not "exist" in our minds. When later, as a young girl, she withdrew within herself, somehow "different," and "apart" from her peers, we attributed it to her artistic talent or independent personality. We did not see or attend to the terror, dissociation, loneliness, and isolation expressed in her drawings, nor did we heed the hints of trouble expressed by her behaviors. Two grade school psychologists were alone among the professionals we encountered in sensing the turbulence underneath her silence. "Anna is confused about her sexual identity," one reported, "you must help her." The other wrote, "It would seem that Anna has suppressed or repressed traumatic incidents."

Chaos and parental conflict existed in Anna's family from the age of 11 to 13 . Though her four brothers and sisters survived the multiple geographic moves, alternative lifestyles, disintegration of their parents' marriage, and episodic violence and alcoholism, Anna did not. She "broke" at the age of 13. A psychiatrist prescribed Haldol to "help her to sleep." She suffered a seizure in reaction, requiring emergency hospitalization. Thus was she introduced to the mental health system.

\section{ANNA'S INVISIBILITY IN THE MENTAL HEALTH SYSTEM}

Anna was a client of the mental health system for 19 years, until age 32. For neàrly 12 of those years, she was institutionalized in psychiatric hospitals. When in the community, she rotated in and out of acute psychiatric wards, psychiatric emergency rooms, crisis residential programs, and locked mental facilities. Principal diagnoses found in her charts included borderline personality with paranoid and schizo-typal features; paranoia; undersocialized conduct disorder aggressive type; and various types of schizophrenia including paranoid, undifferentiated, hebephrenic, and residual. Paranoid schizophrenia was her most prominent diagnosis. Chronic with acute exacerbation, subchronic, and chronic courses of schizophrenia were identified. Symptoms of anorexia, bulimia, and obsessive compulsive personality were also recorded. Treatments included family therapy; vitamin and nutritional therapy; insulin and electroconvulsive "therapy"; psychotherapy; behavioral therapy; art, music, and dance therapies; psychosocial rehabilitation; intensive case management; group therapy; and every conceivable psychopharmaceutical treatment including Clozaril. Ninety-five percent of the treatment approach to her was the use of psychotropic drugs. Though early on there were references to dissociation, her records contain no information about or attempts to elicit the existence of a history of early childhood trauma.

Anna was 22 when she learned, through conversation with other patients who had also been sexually assaulted as children, that she wasn't "the only one in the world." It was then that she was first able to describe to me the details of her abuse. This time, with awareness gained over the years, I was able to hear her.

Events finally became understandable. Sexual torture and betrayal explained her constant screaming as a toddler, her improvement in nursery school, and the re-emergence of her disturbance at puberty. It explained the tears in her paintings, the content of her "delusions," her 
nage of herself as shameful, her self-destructiveness, her involvement prostitution and sadistic relationships, her perception of the world s deliberately hurtful, her isolation, and her profound lack of trust. I nought, with relief and with hope, that now we knew why treatment ad not helped. Here at last was a way to understand and help her heal. The reaction of the mental health system was to ignore this Informaon. When I or Anna would attempt to raise the subject, a look would ome into the professionals' eyes, as if shades were being drawn. If otes were being taken, the pencil would stop moving. We were pushig on a dead button. This remained the case until she took her life, 10 ears and 15 mental hospitals later.

There was one exception. When Anna was 25 years old, the chief sychologist on a back ward of a state hospital listened to her after a ticide attempt, and took what she told him seriously. He initiated a ew treatment approach that addressed her experiences of sexual ouse. Antidepressant medication was prescribed, but psychotropic rugs were viewed as suppressing the thought processes and emotions ne needed to feel fully and begin healing. Rather than relying on drugs ; a solution to escalating stress, Anna was helped through these crises id taught how to deal with them. Art therapy was de-emphasized and $t$ lessons were begun, building her artistic talent and increasing her If-esteem. Discussions began about what she needed so that she could ave the hospital and live in the community.

This situation was not to last. The state hospital was closed because rampant and intractable abuse. Anna's treatment team disbanded. e returned to the system of public mental institutions and community ental health agencies, a world where she was-once again-invisible d undefended. In and out of the "protected environments" of mental alth institutions, she repeatedly experienced coerced or manipulated ‘, verbal and physical abuse, and rape. When she "broke," she became e a three- or four-year-old consumed by rage and terror. The sughts, voices, and nightmares that tormented her were sexual and turing in nature. Violent itches, twitching, stabbing pains, ice cold ts, and innumerable other somatic symptoms invaded her slight ty.

Over her remaining years, in community agencies, acute psychiatric spitalizations, medical and psychiatric emergency rooms, and the $\mathrm{k}$ wards of state mental institutions, she experienced night terrors and insomnia; fears of being taken over by outside forces and of "becoming someone else"; voices telling her she was evil, commanding her to be raped and punished; and eating disorders, dysmenorrhea, and amenorrhea. She painted self-portraits covered with tears, bodies in bondage without hands or arms, and images of multiple persons and sexual acts. She was plagued by intrusive thoughts of abusing her own child, of being tortured, of being "seen" naked by everybody, and of people "getting off sexually" on her torment.

She would often flash back to experiencing her childhood trauma, screaming in terror and pleading for help. On one such occasion, I went with her to a psychiatric emergency service. Calmed enough to answer questions, she stated her diagnosis to be post-traumatic stress disorder. The psychiatrist seemed to be recording this information on the form. When my daughter went over and looked at what she had written, she turned to me and said, "Mom, she wrote down 'schizophrenic.' "

She disclosed in words and behavior fragmented details of the awful things that had happened to her. Once while in restraints she screamed over and over again, "I'm just a sex object, I'm nothing but a sex object." She told her therapist of the "voices" inside her saying "I'm a very young person," "I want you to help me," and "The baby is crying." Once she called her therapist late at night, pleading for her to come to the hospital because "the baby wants to talk to you." Permission was denied by the psychiatrist in charge.

Believing herself to be "bad," "disgusting," and "worthless," as child sexual abuse victims often do, ${ }^{1 \cdot 10}$ she hurt, mutilated, and repeatedly revictimized herself..She put cigarettes out on her arms, legs, and genital area; bashed her head with her fists and against walls; cut deep scars in herself with tom-up cans; stuck hangers, pencils, and other sharp objects up her vagina; swallowed tacks and pushed pills into her ears; attempted to pull her eyes out; forced herself to vomit; dug her feces out so as to keep food out of her body; stabbed herself in the stomach with a sharp knife; and paid men to rape her.

Again and again, as victims of sexual assault often do, ${ }^{1-11}$ Anna sought relief through suicide. She tried to kill herself many timesslashing her wrists, attempting to drown herself, taking drug overdoses, poisoning herself by spraying paint and rubbing dirt into self-inflicted wounds, slitting her throat with a too dull razor, and hanging herself from the pipes of a state hospital. She dared men to kill her-on one 
occasion by throwing her off a bridge and on another by stepping on her back to break it. Many times she would have succeeded had it not been for outside interventions or her own fears of dying or eternal damnation.

Many of the mental health professionals she encountered were highly skilled in their disciplines. Many genuinely cared for Anna; some grew to love her. But in spite of their caring, her experience with the mental health system was a continuing re-enactment of her original trauma. Her perception of herself as "bad," "defective," a "bad seed," or an evil influence on the world was reinforced by a focus on her pathologies, a view of her as having a diseased brain, heavy reliance on psychotropic drugs and forced control, and the silence surrounding her disclosures of abuse.

In the months prior to her death, Anna and I began to reconstruct her story. She completed over 200 pages of detailed memories of her childhood from birth to age 15 . In her own words, including her writings and artwork, and the memories of her brothers, sisters, and others who had been close to her, she spoke her truth. "Mom," she said, "I'm gonna try not to live in these places, because I want to get my life-find some friends-get out some day. Maybe this book will help. Maybe someone will come along and understand me. And they won't just say 'drugs, drugs, drugs!' " She gave her doctor a draft of her book. He did not read it.

Four days after her 32nd birthday, after another haunted sleepless night, she hung herself, by her T-shirt, in the early morning bleakness of her room in a California State mental hospital. She was found by a team of three night staff who were on their way in to give her another shot of medication.

\section{THE WALL OF SILENCE AND INVISIBILITY}

The tragedy of Anna's life is daily replicated in the lives of many individuals viewed as "chronically and severely mentally ill." Unrecognized and untreated for their childhood trauma, they repeatedly cycle through the system's most expensive psychiatric emergency, acute inpatient, and long-term institutional services. Their disclosures of sex- ual abuse are discredited or ignored. As happened during their early childhood, they learn within the mental health system to keep silent.

Clinicians who acknowledge the prevalence of traumatic abuse and recognize its etiological and therapeutic significance are deeply frustrated at being denied the tools and support necessary to respond adequately. Sometimes, as Anna's psychologist did, these clinicians leave the mental health system entirely, deciding they can no longer practice with integrity within it.

A seemingly impenetrable wall of silence isolates the reality and impact of childhood sexual abuse from the consciousness of the public mental health system. No place exists within the system's formal information management structures to receive these data from clients. We do not elicit the information, nor do we record it. Yet to respond therapeutically without such knowledge is analogous to "treating a Vietnam veteran without knowing about Vietnam or what happened there."12 Why, with childhood sexual abuse an open issue for discussion and treatment elsewhere, is it not addressed in the public mental health system?

\section{A PARADIGMATIC EXPLANATION: THE INABILITY TO SEE}

Although rehabilitative, psychotherapeutic, and self-help approaches operate within the system, the dominant paradigm within which these approaches are subsumed is clearly that of biological psychiatry. Thomas Kuhn, in his analysis of the history and development of the natural sciences, ${ }^{13}$ brought the concept of "paradigm" into popular usage. He defined paradigms as "the conceptual networks through which scientists view the world." Data that agree with the scientists' conceptual network are seen with clarity and understanding. But unexpected, "anomalous" data that do not match the scientific paradigm are frequently "unseen," ignored, or distorted to fit existing theories.

In the field of mental health, a biologically based understanding of the nature of "mental illness" has for years been the dominant paradigm. It has determined the appropriate research questions and methodologies; the theories taught in universities and applied in the field; 
the interventions, treatment approaches, and programs used; and the outcomes seen to indicate success.

Paradigmatically understood, the mental health system was constructed to view Anna and her "illness" solely through the conceptual lens of biological psychiatry. The source of her pain, early childhood sexual abuse trauma, was an anomaly - a contradiction to the paradigm, and as such, could not be seen through this lens. Her experience did not match the professional view of mental illness. It did not fit within the system's prevailing theoretical constructs. There was not adequate language available within the professions to articulate or label it. There were not reimbursement mechanisms to cover its "treatment." It was not addressed in curricula for professional training and education, nor was there support for research on the phenomena. There were no tools-treatment, rehabilitation, or self-help interventions-for responding to it. And there was no political support within the field for its inclusion. Screened through the single lens of the biological paradigm, Anna's experience could not be assimilated. It had to be "unseen," rejected, or distorted to fit within the parameters of the accepted conceptual framework.

As a result of this paradigmatic "blindness," conventionally accepted psychiatric practices and institutional environments repeatedly retraumatized Anna, re-enacting and exacerbating the pain and sequelae of her childhood experience. Table 15.1 illustrates that retraumatization.

The effect of this institutional retraumatization was to continually leave Anna "in a condition that fulfilled the prophecy of her pathology." "This was especially true in the use of psychotropic medication. Survivors of trauma tell us the capacity to think and to feel fully is essential for recovery. Psychotropic drugs continually robbed Anna of these capacities. Several years ago, she had been through a crisis period without medication. For days following, she asked for me to hold her. She talked softly about her feelings, crying gently, showing trust through touching and hugs. One day after her newly prescribed meds were beginning to take effect, she said to me with a flatter voice and her eyes again haunted, "Mom, the feeling of love is going away." As her feelings of rage, grief, and terror were suppressed, so were her feelings of love and laughter, caring and intimacy, isolating her again from herself and from others and preventing the possibility of healing.

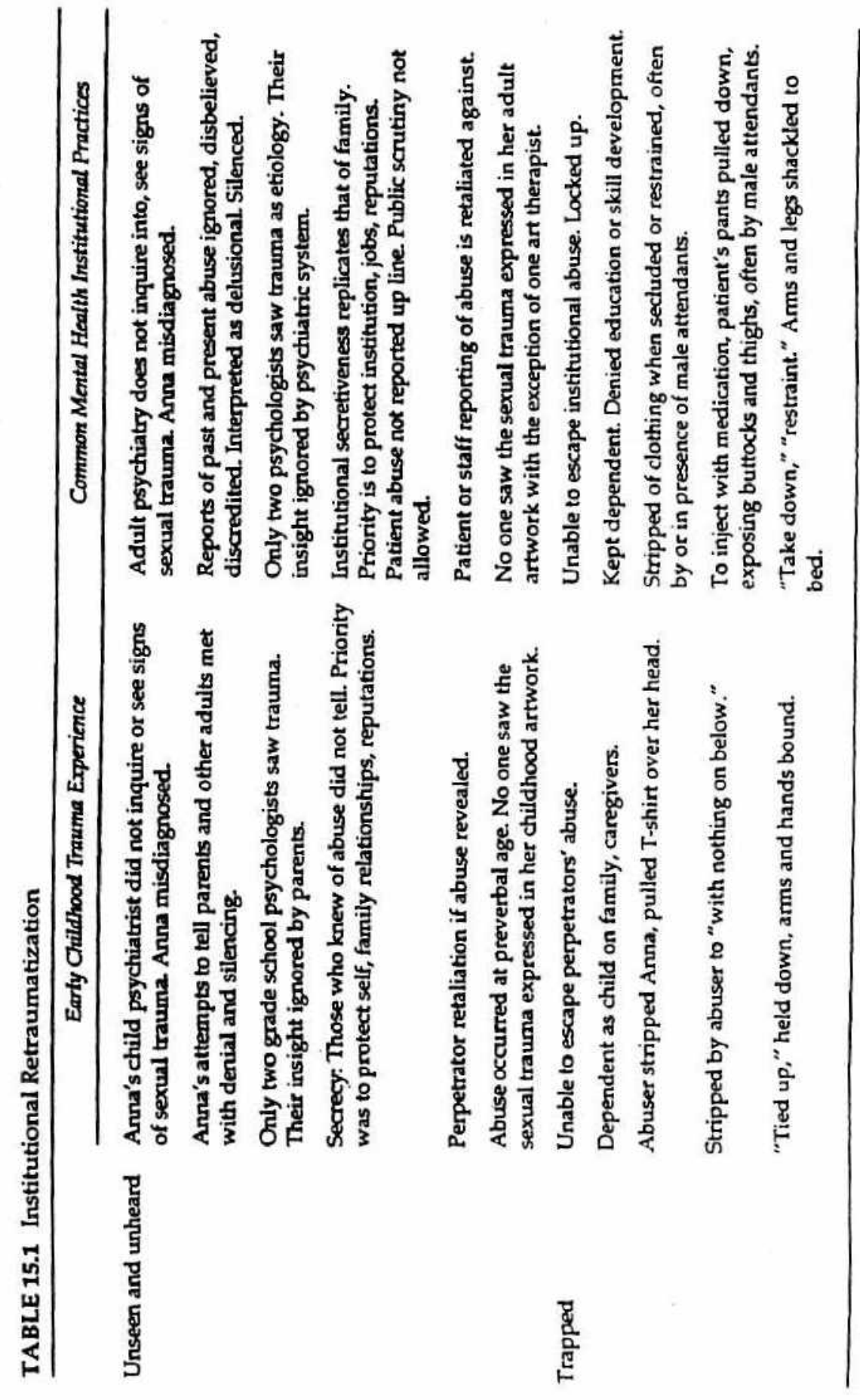

(text continues on $p .338$ ) 
Abuser "blindfolded me with my little T-shirt."

Abuser "opened my legs."

Abuser was "examining and putting things in me."

Boundaries violated. Exposed. No privacy.

Isolated

Taken by abuser to places hidden from others.

Isolated in her experience: "Why just me?"

"I thought I was the only one in the world."

Blamed and shamed

"I had this feeling that I was bad ... a bad seed."

She became the "difficult to handle" child.

She was blamed, spanked, confined to her room for her anger, screams, and cries.

Powerless

Perpetrator had absolute power/control over Anna.

Pleas to stop violation were ignored: "It hurt me. I would cry and he wouldn't stop."
Cloth would be thrown over Anna's face if she spit or screamed while strapped down in restraints.

Forced four-point restraints in spread-eagle position. Medication injected into her body against her will. No privacy from patients or staff. No boundaries. Forced, often by male attendants, into seclusion room. Separated from community in locked facilities.

No recognition of patients' sexual abuse experiences.

Patients stigmatized as deficient, mentally ill, worthless. Abusive institutional practices and ugly environments convey low regard for patients, tear down self-worth.

She became a "noncompliant," "treatment-resistant," difficult-to-handle patient.

Her rage, terror, screams, and cries were often punished by medications, restraint, loss of "privileges," and seclusion.

Institutional staff had absolute power/control over Anna.

Pleas and cries to stop abusive treatment, restraint, seclusion, overmedication, and so forth, commonly ignored.
Expressions of intense feelings, especially anger directed at parents, were often suppressed.

Unprotected

Threatened

Discredited

Crazy-making

Betrayed for her, even in her own home or room.
Anna was defenseless against perpetrator abuse. Her attempts to tell went unheard. There was no safe place

As a child, constant threat of being sexually violated.

As a child, Anna's reports of sexual assault were unheard, minimized, or silenced.

Appropriate anger at sexual abuse seen as something wrong with Anna. Abuse continued, unseen.

Anna's fear from threat of being abused was not understood. Abuse continued, unseen.

Sexual abuse unseen or silenced. Message: "You did not experience what you experienced."

Anna violated by trusted caretakers and relatives.

Disciplinary interventions were "for her own good."

Family relationships fragmented by separation, divorce. Aruna had no one to trust and depend on.
Intense feelings, especially anger at those with more power (all staff), suppressed by medication, isolation, restraint.

Mental patients defenseless against staff abuse. Reports disbelieved. No safeguards effectively protect patients. Personnel policies prevent dismissal of abusive staff.

As mental patient, constant threat of being stripped, thrown into seclusion, restrained, overmedicated.

As a mental patient, Anna's reports of aduit sexual assault were not believed. Reports of child sexual abuse were ignored.

Appropriate anger at abusive institutional practices judged pathological. Met with continuation of practices.

Fear of abusive and threatening institutional behavior is labeled "paranoia" by the institution producing it.

Psychiatric denial of sexual abuse. Message to patient: "You did not experience what you experienced."

Anna retraumatized by helping professionals/psychiatry.

Interventions presented as "for the good of the patient."

Relationships of trust arbitrarily disrupted based on needs of system. No continuity of care or caregiver. 
Medication can be helpful, if used cautiously, with the full understanding and consent of the patient. But without particular knowledge of trauma and of the kinds of medications that can alleviate symptoms and facilitate recovery from trauma, medications can cause incalculable damage. For Anna, the system's reliance on psychopharmaceutical treatment was a metaphor for her original trauma. As séxual assault had violated physical and psychological boundaries of self, forced neuroleptic drugs also intruded past her boundaries, invading, altering, and disabling her mind, body, and emotions. She once said to me, "I don't have a safe place inside myself."

\section{THE EMERGING PARADIGM}

Although the established paradigm may help to alleviate the suffering of those whose mental illness is strictly genetic or biological in nature, it is failing for a significant group whose histories contain sexual and/or physical trauma. Rising cognizance of this failure is one of several factors currently affecting the mental health field, indicating the possibility that a new paradigm, based on trauma, is emerging. The extraordinary resistance to such a paradigm is also indicative of its power and its eventual emergence.

\section{RESISTANCE TO A TRAUMA PARADIGM}

Paradigm shifts, though they mark the way to progress and opportunity, are always initially resisted. They cause change, disrupt the status quo, create tension and uncertainty, and involve more work. ${ }^{15}$ Resistance to a sexual abuse trauma paradigm has existed for over 130 years, during which time the etiological role of childhood sexual violation in mental illness has been alternately discovered, then denied. In 1860 , the prevalence and import of child sexual abuse was exposed by Amboise Tardieu, ${ }^{16}$ in 1896 by Sigmund Freud, ${ }^{17}$ in 1932 by Sandor Ferenczi, ${ }^{18}$ and in $1962^{19}$ and $1984^{20}$ by C. Henry Kempe. Each exposure was met by the scientific community with distaste, rejection, or discredita- tion. Each revelation was countered with arguments that in essence blamed the victims and protected the perpetrators. Freud, faced with his colleagues' ridicule of and hostility to his discoveries, sacrificed his major insight into the etiology of mental illness and replaced his theory of trauma by the view that his patients had "fantasized" their early memories of rape and seduction. ${ }^{16}$ Today, 100 years later, in spite of countless instances of documented abuse, this tradition of denial and victim-blame continues to thrive.

Psychiatrist Roland Summit refers to this denial as "nescience" or "deliberate, beatific ignorance." He proposes that "in our historic failure to grasp the importance of sexual abuse and our reluctance to embrace it now, we might acknowledge that we are not naively innocent. We seem to be willfully ignorant, nescient." ${ }^{21}$

At this point in history, however, multiple and divergent forces are confronting nescience with truth. Although these forces will continue - to meet resistance, they appear to be forming a powerful movement that will help to protect children from adult violation and will promote acceptance of a trauma-based paradigm recognizing the pain of individuals like my daughter and offering them "the radical prospect of recovery." 21

\section{IMPLICATIONS FOR MENTAL HEALTH ADMINISTRATORS AND POLICYMAKERS}

Mental health administrators and policymakers are in a unique position today to prevent the re-creation of tragedies such as my daughter Anna's. The tools and resources they need to do so can be found in the following forces supporting the emergence of the new trauma paradigm.

- Among the most significant forces for change are the victims themselves. For the first time in history, survivors of sexual trauma are speaking out-revealing their experiences of having been sexually violated as children, lobbying politically for services and legislative action, challenging societal denial and nescience, and keeping the reality of the 
sexual assault of children in the arena of public awareness. Growing numbers of these survivors are recipients of mental health services and former mental patients with post-traumatic stress and dissociative disorders. After years of hospitalization and misdiagnoses such as borderline personality disorder, major depression, and schizophrenia, they talk of how they could not have begun to heal had not someone recognized and responded therapeutically to their childhood experiences of abuse and torture. Finally, ex-patients in the mainstream consumer movement are beginning to reveal their experiences of sexual violation, the ways in which they felt retraumatized by treatment in psychiatric hospitals and institutions, and their ongoing struggle to heal from both childhood abuse and adult institutional revictimization.

- The number of studies, instruments, articles, books, and professional journals based on a trauma paradigm is multiplying, making visible the most hidden and most damaged victims of childhood sexual assault, and heightening awareness of such anomalies to the psychiatric paradigm. Research is revealing significantly higher prevalence rates of childhood sexual abuse among female psychiatric outpatients and inpatients (as high as 70 percent) ) $^{2.22}$ than is found in the general population. Many of these clients require emergency, acute inpatient care and long-term hospitalization services. ${ }^{21,11,21-18}$ Studies establish a history of childhood sexual trauma to have significant implications for diagnosis and treatment, $1,2,4,8,21,22,24,25,27.31,33,35,36,38,40,41,46 \cdot .84$ and the routine inquiry about childhood sexual abuse to be an essential component of emergency, acute inpatient and outpatient psychiatric protocols. ${ }^{2,23,28,30,36,37,65,85-47}$ The growing pool of data indicates that when trauma is recognized and responded to in specific therapeutic interaction, possibilities of recovery exist even for those survivors of sexual abuse who are viewed as schizophrenic, depressive, or border-

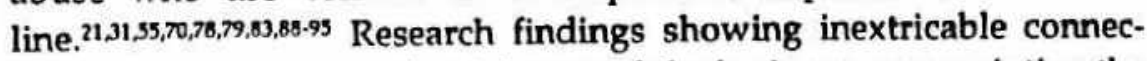
tions between trauma, physiology, and the brain are now pointing the way to new relationships between these areas of data under a trauma paradigm. .6

- Political support for a new trauma paradigm is growing as government-sanctioned committees are formed and local, state, and federal governing bodies pass legislation requiring mental health systems to address issues of physical and sexual abuse trauma in their clients. One such notable step is a 1993 congressional mandate directing the national Center for Mental Health Services (CMHS) to pay attention to women's issues. After surveying the field, CMHS established its priority focus to be on physical and sexual abuse in the lives of women with severe mental illness.

- New therapeutic approaches to sexual and other trauma in persons with serious mental illness are being used and developed outside of and on the fringes of the public mental health system. Examples can be found in the-dissociative disorder units of private psychiatric hospitals; in the work of art therapists using imagery and play therapy with traumatized children; in the treatment of severely traumatized war veterans; in the specialized victims and offenders services now serving individuals with severe mental illness; in incest survivor self-help groups; in rape treatment centers; increasingly in the field of child psychiatry; and in the work of private therapists.

- Respected national and international professional associations focused on researç and treatment of severely traumatized children and adults have formed over the past decade, and networks of professionals, advocates, and ex-patient survivors increasingly proliferate.

- Women's rights and mental health litigators are being asked to recognize the connection between sexual violence, "craziness," and the treatment of women in psychiatric institutions. These connections are seen to have consequences for rights to treatment, rights to refuse treatment, and forced medication and seclusion and restraint cases. ${ }^{14}$

- Finally, a powerful force for paradigmatic change at this time in history is the advent of health care reform, introducing managed care, capitation, and the need for public mental health organizations to compete in providing quality services to consumers in a cost-effective way. Incorrect diagnoses and treatment exacerbates the condition of traumatized patients, making them dependent on the system's most restrictive and expensive services. An analysis of 17 years of Anna's records shows 
that she was hospitalized a total of 4,124 days. The total cost for this hospitalization, figured at $\$ 640$ a day, was $\$ 2,639,360$ ! Not included in this analysis is the cost of social services, police, ambulance and legal/court services, conservator and patient advocacy services, residential treatment, psychiatric and therapist sessions, crisiş, services, day programs, and intensive case management estimated to be over $\$ 500,000$ for a total cost of over $\$ 3,000,000$. By comparison, intensive trauma-based psychotherapy, figured at $\$ 150$ a session, two sessions a week, for 17 years, would have cost a total of $\$ 265,200$. With studies showing prevalence rates as high as 81 percent ${ }^{37}$ of hospitalized patients to have histories of sexual and/or physical trauma, the fiscal implications to exploring a trauma paradigm are obvious.

\section{CONCLUSION}

The ideas, practices, and standard operating procedures that got the public mental health field and its various agencies and institutions to where they are today will clearly not take them into the future. The rules have changed dramatically. Forces shaping a new paradigm include: health care reform and managed care; the need to compete and to deliver quality services in cost-effective ways; the emergence of political activism and public testimony on the part of ex-patient survivors of trauma; the proliferation of research and writing about sexual trauma and serious mental illness; the intense interest and debate around the import of sexual abuse for treatment; the developing legal interest in the system's retraumatization of sexually abused patients; the growth of private psychiatric hospital services for persons with dissociative disorders; and finally, the advances around the fringes of the public mental health field providing evidence that, when trauma is recognized and responded to therapeutically, actual recovery is possible for persons with histories of hospitalization and use of the most expensive services of the system. Resources for "re-tooling" the mental health system to effectively address trauma are to be found in the forces pushing the field to change. Institutions, agencies, and systems that ignore the opportunities presented by the new trauma paradigm do their clients an injustice.

\section{REFERENCES}

1. Briere J, Runtz M: Post sexual abuse trauma. In: Wyatt GE, Powell GJ (Eds.): Lasting Effects of Child Sexual Abuse. Newbury Park, CA: Sage, 1988, pp. 85-99.

2. Briere J, Zaidi LV: Sexual abuse histories and sequelae in female psychiatric emergency room patients. American Journal of Psychiatry 1989; 12:1602-1606.

3. Briere J, Evans D, Runtz M, et al.: Symptomatology in men who were molested as children: A comparison study. American Joumal of Orthopsychiatry 1988; 58:457.461.

4. Brown GR, Anderson B: Psychiatric morbidity in adult inpatients with child hood histories of sexual and physical abuse. American Joumal of Psychiatry 1991; 148:55-61.

5. Bulik CM, Sullivan PF, Rorty M: Childhood sexual abuse in women with bulimia Joumal of Clinical Psychiatry 1989; 50:460-464.

6. Coons PM, Bowman ES, Milstein V: Multiple personality disorder: A clinical investigation of 50 cases. Journal of Nervous and Mental Disease 1988; 176:519-527.

7. Garnefski N, Egmond M, Straatman A: The influence of early and recent life stress on severity of depression. Acta Psychiatrica Scandinavica 1990; 81:295-301.

8. Heins T, Gray A, Tennant M: Persisting hallucinations following childhood sexual abuse. Australian and New Zealand Joumal of Psychiatry 1990; 24:561-565.

9. Rew L: Long-term effects of childhood sexual exploitation. Issues in Mental Health Nursing 1989; 10:229-244.

10. Riggs S, Alario AJ, McHorney C: Health risk behaviors and attempted suicide in adolescents who report prior maltreatment. Joumal of Pediatrics 1990; 116:815-821.

11. Ross CA, Norton GR, Wozney K: Multiple personality disonder: An analysis of 236 cases. Canadian Joumal of Psychiatry. Reoue Canadienne de Psychiatrie 1989; 34:413-418.

12. Gise LH, Paddison P: Rape, sexual abuse, and its victims. Psychiatric Clinics of North America 1988; 11:629-648.

13. Kuhn TS: The Structure of Scientific Revolutions. Chicago: University of Chicago Press, 1972.

14. Stefan S: The Protection Racket: Violence Against Women: Psychiatric Labelling and Law. Miami, FL: University of Miami, 1993.

15. Barker JA: Discovering the Future: The Buisiness of Paradigms (video). Charthouse Learning Corporation, 221 River Ridge Circle, Burnsville, MN 55337.

16. Masson JM: The Assault on Truth: Freud's Suppression of the Seduction Theory. New York: Farrar, Straus and Giroux, 1984.

17. Freud S: The aetiology of hysteria (1896). In: The Standard Edition of the Complete Psychological Works of Sigmund Freud. London: Hogarth Press and the Institute of Psychoanalysis, 1953-1974, pp. 191-221.

18. Ferenczi S: Confusion of tongues between adults and the child: The language of tenderness and the language of [sexual] passion. (1932) [Translation by Jeffrey M. Masson and Marianne Loring] In: Masson JM: The Assault on Truth: Freud's Suppression of the Seduction Theory. New York: Farrar, Straus and Giroux, 1984, Appendix C, pp. 283-295.

19. Kempe $\mathrm{CH}$, Silverman FN, Steele BF, et al.: The battered-child syndrome. Journal of the American Medical Association 1962; 181:17-24.

20. Kempe RS, Kempe CH: The Common Secret: Sexual Abuse of Children and Adolescents. New York: Freeman, 1984.

21. Summit R: The centrality of victimization: Regaining the focal point of recovery for survivors of child sexual abuse. Psychiatric Clinics of North America 1989; 12:413-450. 
22. Briere J, Runtz M: The long-term effects of sexual abuse: A review and synthesis. New Directions for Mental Health Services 1991; 51:3-13.

23. Rose SM, Peabody CG, Stratigeas B: Undetected abuse among intensive case management clients. Hospital and Community Psychiatry 1991; 42:499-503.

24. Beck JC, van der Kolk B: Reports of childhood incest and current behavior of chronically hospitalized psychotic women. American Joumal of Psychiatry 1987; 144:14741476.

25. Bigras J, Leichner $P$, Perreault $M$, et al.: Severe paternal sexual abuse in early childhond and systematic aggression against the family and the institution. Canadian Jour. nal of Psychiairy 1991; 36:527-529.

26. Browne A, Finkelhor D: Impact of child sexual abuse: A review of the literature. Psychological Bulletin 1986; 99:66-77.

27. Bryer JB, Nelson BA, Miller JB, et al.: Childhood sexual and physical abuse as a factor in adult psychiatric illness. American Joumal of Psychiatry 1987; 144:1426-1430.

28. Carmen EH, Rieker PP, Mills T: Victims of violence and psychiatric illness. American lourmal of Psychiatry 1984; 141:378-383.

29. Chu JA, Dill DL: Dissociative symptoms in relation to childhood physical and sexual abuse. American Journal of Psychiatry 1990; 147:887-892.

30. Cole C: Routine comprehensive inquiry for abuse: $\mathrm{A}$ justifiable clinical assessment procedure? Clinical Social Work Journal 1988; 16:33-42.

31. Coons PM, Bowman ES, Pellow TA, et al.: Post-traumatic aspects of the treatment of victims of sexual abuse and incest. Psychiatric Clinics of North America 1989; 2:325-335.

32. Craine LS, Henson CE, Colliver JA, et al.: Prevalence of a history of sexual abuse among female psychiatric patients in a state hospital system. Hospital and Community Psychiatry 1988; 39:300-304.

33. Den Herder D, Redner L: The treatment of childhood sexual trauma in chronically mentally ill adults. Health and Social Work 1991; 16:50-57.

34. Edwards PW, Donaldson MA: Assessment of symptoms in adult survivors of incest: A factor analytic study of responses to child hood incest questionnaire. Child Abuse $E$ Neglect 1989; 13:101-110.

35. Herman J, Russell D. Trocki K: Long-term effects of incestuous abuse in childhood. American Journal of Psychiatry 1986; 143:1293-1296.

36. Jacobson A, Herald C: The relevance of childhood sexual abuse to adult psychiatric inpatient care. Hospital and Community Psychiatry 1990; 41:154-158.

37. Jacobson A, Richardson B: Assault experiences of 100 psychiatric inpatients: Evidence of the need for routine inquiry. American joumal of Psychiatry 1987; 144:908-913.

38. Margo GM, McLees EM: Further evidence for the significance of a childhood abuse history in psychiatric inpatients. Comprehensive Psychiatry 1991; 32:362-366.

39. Muenzenmaier K, Meyer I, Struening E, et al.: Childhood abuse and neglect among women outpatients with chronic mental illness. Hospital and Community Psychiatry 1993; 44:666-670.

40. Post RD, Willett AB, Franks RD, et al.: A preliminary report on the prevalence of domestic violence among psychiatric inpatients. American Journal of Psychiatry 1980; 137:974-975.

41. Rose SM, Peabody CG, Stratigeas B: Responding to hidden abuse: A role for social work in reforming mental health systems. Social Work 1991; 36:408-413.

42. Rosenfeld A: Incidence of a history of incest among $\mathbf{1 8}$ female psychiatric patients. American loumal of Psychialry 1979; 136:791-795.
43. Ross CA, Norton R: Multiple personality disorder patients with a prior diagnosis of schizophrenia. Dissociation 1988; 1:39-42.

44. Ross CA, Anderson G, Fleisher WP, et al.: The frequency of multiple personality disorder among psychiatric inpatients. American lournal of Psychiatry 1991; 148:1717. 1720.

45. Ross CA, Miller SD, Bjornson L, et al.: Abuse histories in 102 cases of multiple personality disorder. Canadian Joumal of Psychiatry 1991; 36:97-101.

46. Surrey J, Swett C Jr, Michaels A, et al.: Reported history of physical and sexual abuse and severity of symptomatology in women psychiatric outpatients. American lou mal of Orthopsychiatry 1990; 60:412-417.

47. Swett C Jr, Surrey J, Cohen C: Sexual and physical abuse histories and psychiatric symptoms among male psychlatric outpatients. American Journal of Psychiatry 1990; 147:632-636.

48. Carmen EH, Rieker PP: A psychosocial model of the victim-to-patient process: Implications for treatment. Psychiatric Clinics of North America 1989; 12:431-443.

49. Rose SM: Acknowledging abuse backgrounds of intensive case management clients. Community Mental Health Joumal 1991; 27:255-263.

50. van der Kolk BA, Perry JC, Herman JL: Childhood origins of self-destructive behavior. American Jourmal of Psychiatry 1991; 148:1665-1671.

51. van der Kolk BA: The compulsion to repeat the trauma: Re-enactment, revictimization, and masochism. Psychiatric Clinics of North America 1989; 12:389-411.

52. Chase T: When Rabbit Howls. New York: Dutton, 1987.

53. Dell PF, Eisenhower JW: Adolescent multiple personality disorder: A preliminary study of eleven cases. Joumal of the American Academy of Child and Adolescent Psychiatry 1990; 29:359-366.

54. Emslie GJ, Rosenfeld A: Incest reported by children and adolescents hospitalized for severe psychiatric problems. American Journal of Psychiatry 1983; 140:708-711.

55. Finkelhor D, Araji S, Baron L, et al.: A Sourcebook on Child Sexual Abuse. Beverly Hills, CA: Sage, 1986.

56. Gelinas DF: The persisting negative effects of incest. Psychiatry 1983; 46:312-332.

57. Goff DC, Brotman AW, Kindlon D, et al.: The delusion of possession in chronically psychotic patients. Joumal of Nervous and Mental Disease 1991; 179:567-571.

58. Goff DC, Brotman AW, Kindlon D, et al.: Self-reports of childhood abuse in chronically psychotic patients. Psychiatry Research 1991; 37:73-80.

59. Goodwin JM, Cheeves K, Connel V: Defining a syndrome of severe symptoms in survivors of extreme incestuous abuse. Dissociation 1989; 1:11-16.

60. Goodwin JM, et al.: Borderline and other severe symptoms in adult survivors of incestuous abuse. Psychiatric Annals 1990; 20:22-32.

61. Hart LE, Mader L, Griffith K, et al.: Effects of sexual and physical abuse: A comparison of adolescent inpatients. Child Psychiatry and Human Development 1989; 20:49-57.

62. Herman JL, van der Kolk BA: Traumatic antecedents of borderline personality disorder, In: van der Kolk BA (Ed.): Psychological Trauma. Washington, DC: American Psychiatric Press, 1987, pp. 111-126.

63. Herman JL, Perry JC, van der Kolk BA: Childhood trauma in borderline personality disorder. American Journal of Psychiatry 1989; 146:490-495.

64. Herman JL: Father-Daughter Incest. Cambridge, MA: Harvard University Press, 1981

65. Jacobson A: Physical and sexual assault histories among psychiatric outpatients. American Journal of Psychiatry 1989; 146:755-758. 
66. Kinzl J, Biebl W, Hinterhuber $\mathrm{H}$ : The significance of incest experience for the development of psychiatric and psychosomatic diseases. Nervenarzt 1991; 62:565-569.

67. Kluft RP: Childhood Antecedents of Multiple Personality. Washington, DC: American Psychiatric Press, 1985.

68. MacFarlane K, Waterman J, Conerly S, et al.: Sexual Abuse of Young Children. New York: Guilford, 1986.

69. Paddison PL, Gise LH, Lebovits A, et al: Sexual abuse and premenstrual syndrome: Comparison between a lower and higher socioeconomic group. Psychosomatics 1990; 31:265-272.

70. Patten SB, Gatz YK, Jones B, et at.: Post-traumatic stress disorder and the treatment of sexual abuse. Social Work 1989; 34:197-203.

71. Peters F: Children who are victims of sexual assault and the psychology of offenders. American loumal of Psychotherapy 1976; 30:398-432.

72. Pribor EF, Dinwiddie SH: Psychiatric correlates of incest in childhood. American lournal of Psychiatry 1992; 149:52-56.

73. Russell DEH: The Secret Trauma: Incest in the Lives of Girls and Women. New York: Basic Books, 1986.

74. Stein JA, Golding JM, Siegel JM, et al.: Long-term psychological sequelae of child sexual abuse: The Los Angeles Epidemiologic Catchment Area study. In: Wyatt GA, Powell GJ (Eds.): Lasting Effects of Child Sexual Abuse. Beverly Hills, CA: Sage, 1988, pp. 135-154.

75. Summit RC: Recognition and treatment of child sexual abuse. In: Hollingsworth $C$ (Ed.): Textbook of Pediatric Consultation-Liaison Psychiatry. New York: Spectrum, 1983.

76. Summit RC: The child sexual abuse accommodation syndrome. Child Abuse \& Neglect 1983; 7:177-193.

77. Summit RC: Critical issues in counseling. In: Protecting Our Children: The Fight Against Molestation: A National Symposium. Washington, DC: U.S. Department of Justice, 1984

78. Summit RC: Hidden victims, hidden pain: Societal avoidance of child sexual abuse. In: Wyatt GA, Powell GJ (Eds.): Lasting Effects of Child Sexual Abuse. Beverly Hills, CA: Sage, 1988, pp. 39-60.

79. van der Kolk BA (Ed.): Psychological Trauma. Washington, DC: American Psychiatric Press, 1987.

80. van der Kolk BA (Ed.): Post-Traumatic Stress Disorder: Psychological and Biological Sequelae. Washington, DC: American Psychiatric Press, 1984.

81. Whitman BY, Munkel W: Multiple personality disorder: A risk indictor, diagnostic marker and psychiatric outcome for severe child abuse. Clinical Pediatrics 1991; 30:422-428.

82. Whitwell $D$ : The significance of childhood sexual abuse for adult psychiatry. British lournal of Hospital Medicine 1990; 43:346-352.

83. Wyatt GA, Powell G] (Eds.): Lasting Effects of Child Sexual Abuse. Newbury Park, CA: Sage, 1988.

84. Young WC, Sachs RG, Braun BG, et al.: Patients reporting ritual abuse in childhood: A clinical syndrome: Report of 37 cases. Child Abuse \& Neglect 1991; 15:181-189.

85. Ross CA, Miller SD, Reaagor P, et al.: Structured interview data on 102 cases of multiple personality disorder from four centers. American Journal of Psychiatry 1990; 147:596-601.

86. Goodwin J, Attiass R, McCarty T, et al.: Effects on psychiatric inpatients of routine questioning about childhood sexual abuse. Victimology, in press.
87. Jacobson A, Koehler J, Jones-Brown C: The failure of routine assessment to detect histories of assault experienced by pyychiatric patients. Hospilal and Community Psy-
chintry 1987; 38:386-389.

88. Goodwin JM, Talwar N: Group psychotherapy for victims of incest. Psychiatric Clinics of North America 1989; 2:279-293.

89. Goodwin JM: Applying to adult incest victims what we have learned from victimized children. In: Kluft R (Ed.): Incest-Related Syndromes of Adult Psychopathology. Washington, DC: American Psychiatric Press, 1990, pp. 55-74.

90. Herman JL: Trauma and Recovery: The Aflermalh of Violence-From Domestic Abuse to Political Terror. New York: Basic Books, 1992.

91. Putnam FW: The treatment of multiple personality: State of the art. In: Braun BG (Ed.): Treatment of Multiple Personality Disorder. Washington, DC: American Psychiatric Press, 1986.

92. Putnam FW: Diagnosis and Treatment of Multiple Personality Disorder. New York: Guilford, 1989.

93. Ross CA: Multiple Personality Disorder: Diagnosis, Clinical Features and Treatment. New York: Wiley, 1989.

94. Wilbur CB: Treatment of multiple personality. Psychiatric Annals 1984; 14:2-31.

5. Wilbur CB: The effect of child abuse on the psyche. In: Kluft RP (Ed.): Childhood Antecedents of Multiple Personality. Washington, DC: American Psychiatric Press, 1985, pp. 22-35.

96. van der Kolk BA: The body keeps the score: Memory and the evolving psychobiology of post-traumatic stress. Harvard Review of Psychiatry 1994; 1:253-265. 